\title{
Giant condyloma acuminata: Incidence among cases diagnosed as carcinoma of the penis
}

\author{
SYLVIA W. DAVIES \\ From the Department of Pathology, University of Liverpool
}

SYNOPSIS Twenty-four cases of giant condyloma acuminata were found among 100 cases diagnosed as carcinoma of the penis. One of the 24 tumours showed early malignant change. The characteristic histological pattern of giant condyloma consists of broad processes composed of prickle cells associated with little keratinization. The malignant condylomas show, in comparison, a loss of prickle cell preponderance, increased basal cell activity and frequent keratinization, or may present as a solid papillary epithelioma forming broad sheets of uniform cells with many mitoses. The incidence of malignant change in the giant condyloma and the relationship between the benign and malignant tumours are discussed.

Giant condyloma acuminata is an extensive warty tumour of the penis often mistaken clinically for carcinoma. It is cured by adequate, though conservative, surgical treatment.

Buschke (1896) described the clinical features of the tumour and Buschke and Loewenstein (1932) and Loewenstein (1939) defined the histological structure which is identical to that of the small non-venereal genital wart; lymph nodes are invariably free from metastases. About 40 cases have been reported in the literature (Mühlpfordt, 1928 and 1931; Frei, 1930; Freudenthal and Spitzer, 1933; Treite, 1941; Gersh, 1953; Dreyfuss and Neville, 1955; Fisher and Hass, 1955; Montagnani, 1957; Lepow and Leffler, 1960; Davies, 1964; Powley, 1964).

\section{OUTLINE OF THE INVESTIGATIONS}

Cases diagnosed both clinically and pathologically as carcinoma of the penis were analysed in order to demonstrate the true incidence of giant condyloma acuminata. The histological sections and case records were obtained of 100 cases notified as carcinoma of the penis to the Liverpool Central Cancer Organization over the years 1946-63. The sections were examined first and, according to the type of tumour observed, the cases were divided into groups (Table I). The clinical details of the cases were analysed separately (Table II), and, finally, both the histological and clinical features in each group were combined and compared. To some extent the terminology used to define each histological group Received for publication 22 June 1964. follows the nomenclature of the German dermatopathologists (Unna, 1894; Delbanco, 1925; Israel, 1928a, b; Frei, 1930).

\section{PATHOLOGICAL DESCRIPTION OF TUMOURS}

GROUP A: GIANT CONDYLOMA ACUMINATA The giant

TABLE I

\begin{tabular}{llc} 
Group & Histological Type & No. of \\
& & Cases \\
\hline I & Giant condyloma acuminata, including one & 24 \\
II & case with early malignant change & \\
III & Malignant condyloma & 15 \\
IV & Solid papillary epithelioma & 17 \\
V & Squamous cell carcinoma & 35 \\
VI & Basal cell carcinoma & 4 \\
& Miscellaneous tumours & 5
\end{tabular}

TABLE II

CLINICAL DETAILS OF 100 CASES DIAGNOSED AS CARCINOMA OF THE PENIS SUBDIVIDED INTO HISTOLOGICAL GROUPS

\begin{tabular}{lcccccc} 
& \multicolumn{7}{c}{ Group } & & & & \\
\cline { 2 - 7 } & $A$ & $B$ & $C$ & $D$ & $E$ & $F$ \\
\hline No. of cases & 24 & 15 & 17 & 35 & 4 & 5 \\
Mean age (yr.) & 63 & 64 & 66 & 60 & 62 & - \\
Range (yr.) & $35-94$ & $47-77$ & $42-77$ & $30-88$ & $55-88$ & - \\
Duration of symptoms (mth.) & 39 & $7 \cdot 5$ & $5 \cdot 5$ & $7 \cdot 5$ & 21 & - \\
Range (mth.) & $1-360$ & $1-36$ & $1-18$ & $1-60$ & $1-48$ & - \\
Circumcised & 0 & 0 & 0 & 4 & 0 & 0 \\
Died from carcinoma penis & 0 & 3 & 4 & 13 & 1 & 2 \\
Died from other causes & 7 & 4 & 1 & 7 & 0 & 0 \\
Alive after 5 years & 11 & 7 & 12 & 13 & 3 & 2 \\
Alive under 5 years & 6 & 1 & 0 & 2 & 0 & 1 \\
Lymph node metastases & $0 / 2$ & $1 / 2$ & $2 / 3$ & $7 / 7$ & - & $2 / 2$
\end{tabular}


condyloma acuminata may be relatively small and localized or it may extend over a wide area involving the glans, prepuce, and shaft of the penis (Fig. 1). It may present clinically with perforation of the prepuce (Fig. 2) or with urethral fistula (Gersh, 1953; Lepow and Leffler, 1960; Davies, 1964) and there is frequently gross secondary infection.

Microscopically (Figs. 3-6) the tumour forms a luxuriant mass composed of broad, rounded processes which often extend far into the underlying tissues. The lower limits of the processes tend to lie at an equal depth from the surface and are surrounded by a dense band of acute and chronic inflammatory cells. The processes are composed primarily of many layers of typical prickle cells with finely marked intercellular bridges. At the periphery there may be one or several layers of basal cells which show little variation either in cellular arrangement or in the size and staining properties of the nuclei, but occasional mitoses are seen. Centrally the prickle cells tend to become larger, pale and finely outlined; intercellular bridges are less prominent but oval nuclei with acidophil nucleoli are retained. Cavities which contain many polymorphonuclear leucocytes, lymphocytes, and plasma cells are often conspicuous in the central areas. Free nucleated epithelial cells with faint acidophil staining may also be present. Keratinization is infrequent and is only found to occur within processes which are adjacent to the surface or in relation to the deep sulci formed by the warty projections. Small rounded areas of typical tumour which appear close to the main papillary mass are often the tips of processes which have become isolated by tangential cutting of the section.

With the exception of one case in which malignant change occurred as an isolated area (case 3) it was found that the pattern of giant condyloma which has been described was constant throughout all parts of the tumours which were examined. In addition, the squamous epithelium of the whole area, including that of the prepuce and anterior urethra, showed a similar hypertrophy of the prickle cell layers (Fig. 7).

GROUP B: THE MALIGNANT CONDYLOMA (FIGS. 8, 9) There are several features by which the malignant condyloma can be differentiated from the giant condyloma. The processes tend to be multiple, narrow and small; they may be irregular in outline and the lower limits vary in depth. There is a reduction in the number of prickle cells and these are replaced by the large, pale, finely outlined cells without intercellular bridges seen only towards the central areas of the giant condyloma; these cells may be vacuolated or contain two or three nuclei

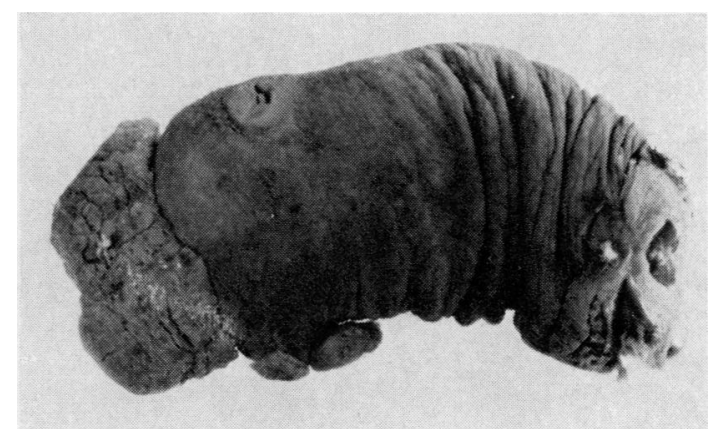

FIG. 1. Cross specimen showing perforation of prepuce.

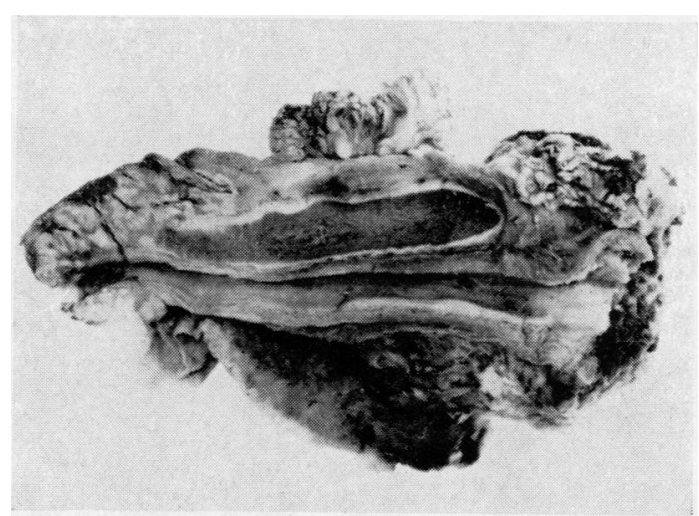

FIG. 2. Sagittal section of a specimen showing distribution of tumour.

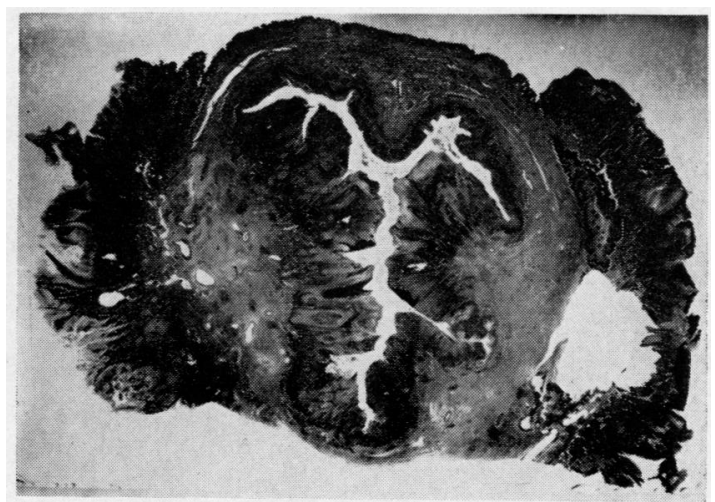

FIG. 3. Cross section of a phimotic prepuce showing giant condyloma $\times 4$.

and occasional mitoses occur. The basal cells at the periphery are multiple and show disorderly cellular arrangement, variation in size and staining, and frequent mitoses. The central areas often contain much keratohyaline material in addition to inflammatory cells, so that acidophil staining is prominent. 


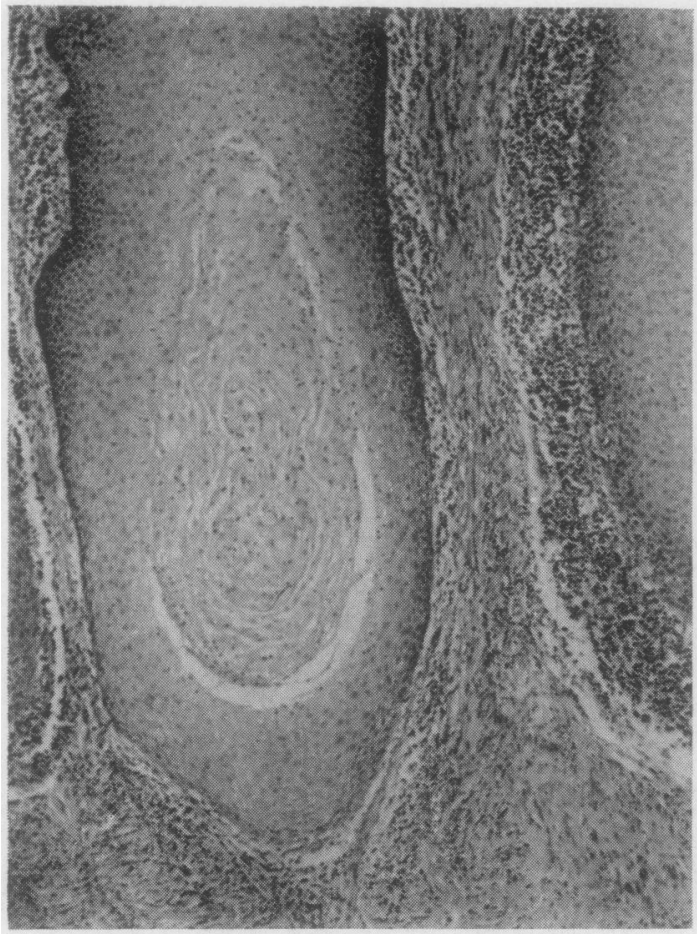

FIG. 4

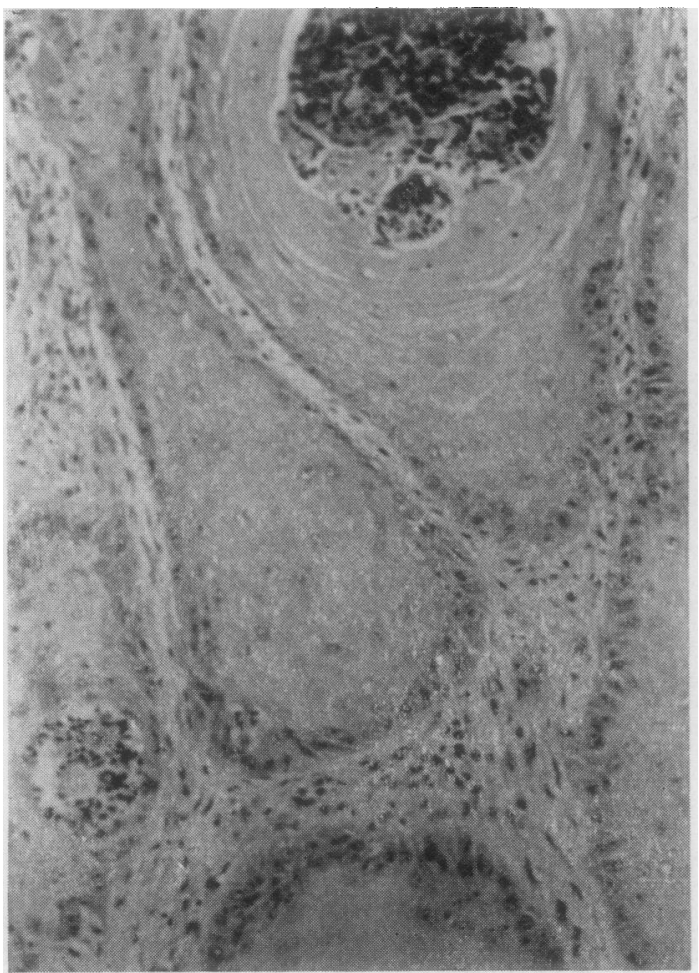

FIG. 5

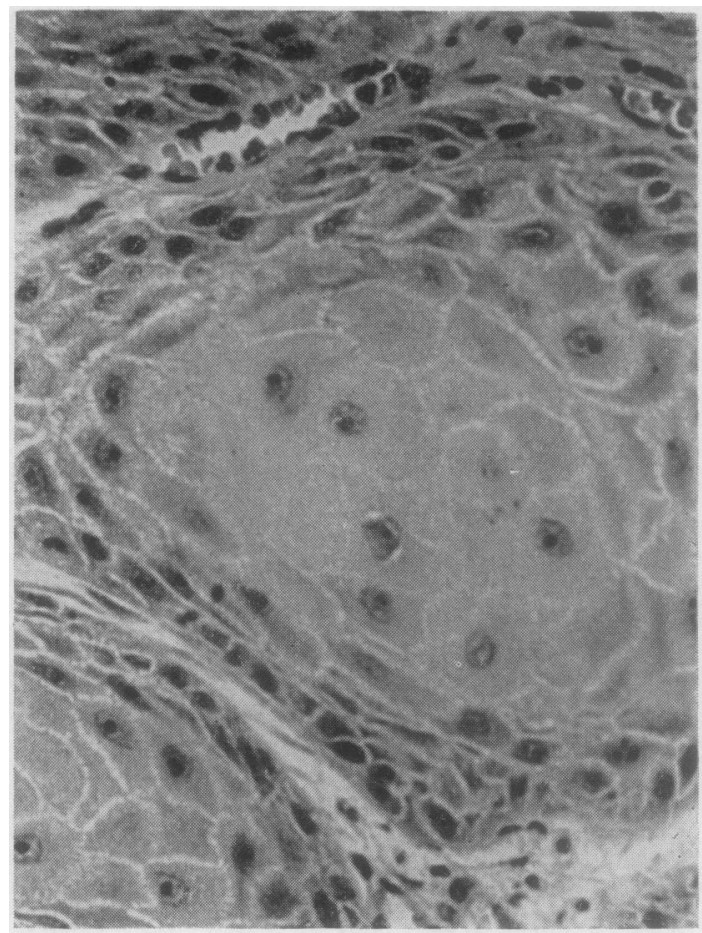

FIG. 6

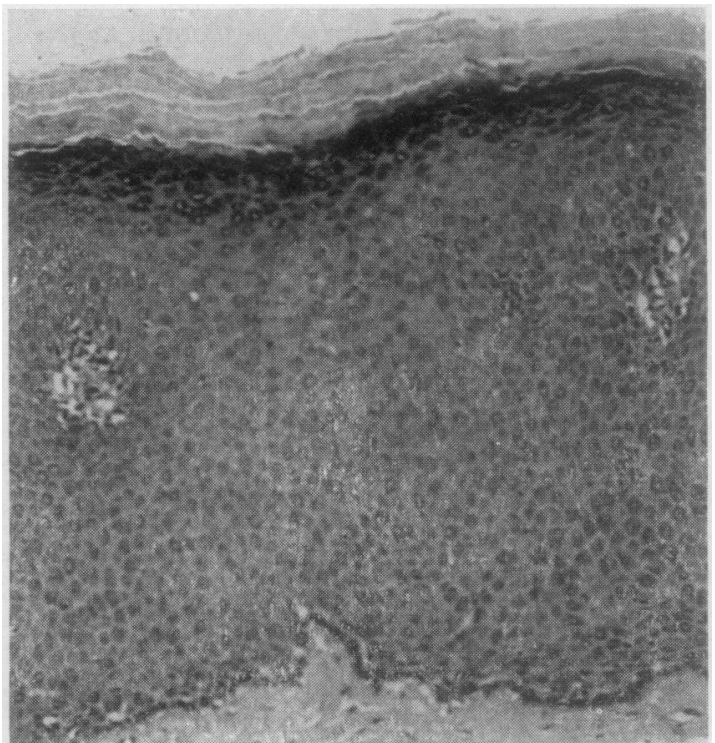

FIG. 7

FIG. 4. Typical process with surrounding inflammatory cells $\times 10$

FIG. 5. Several processes with centres containing inflammatory cells and debris $\times 25$.

FIG. 6. Typical process showing prickle cells $\times 40$. FIG. 7. Local epithelium $\times 10$. 


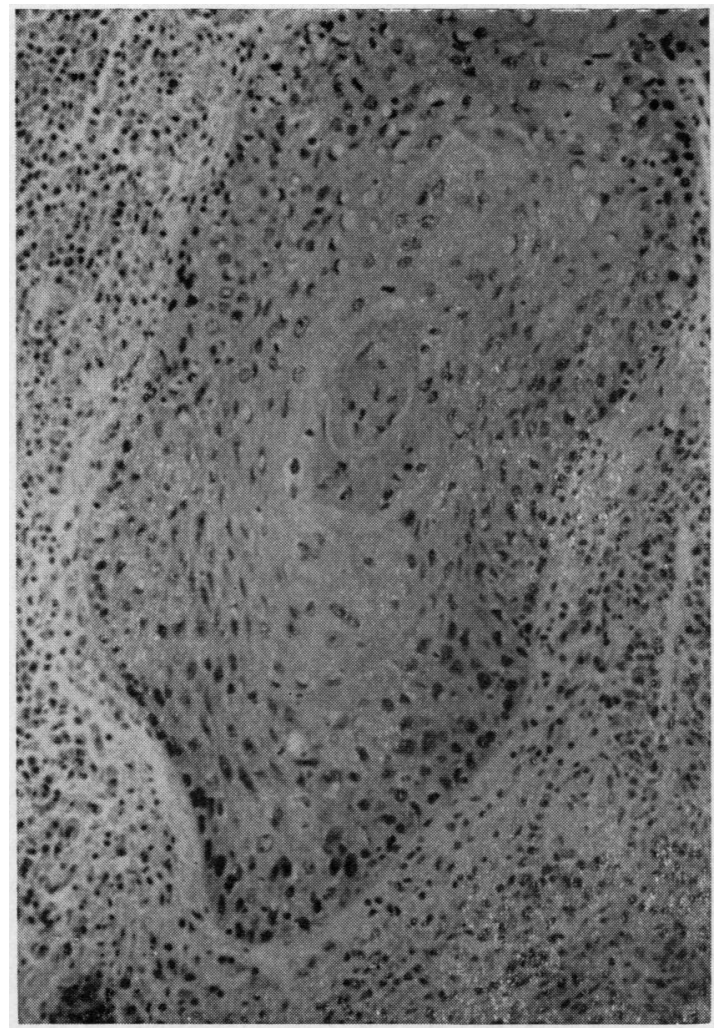

FIG. 8

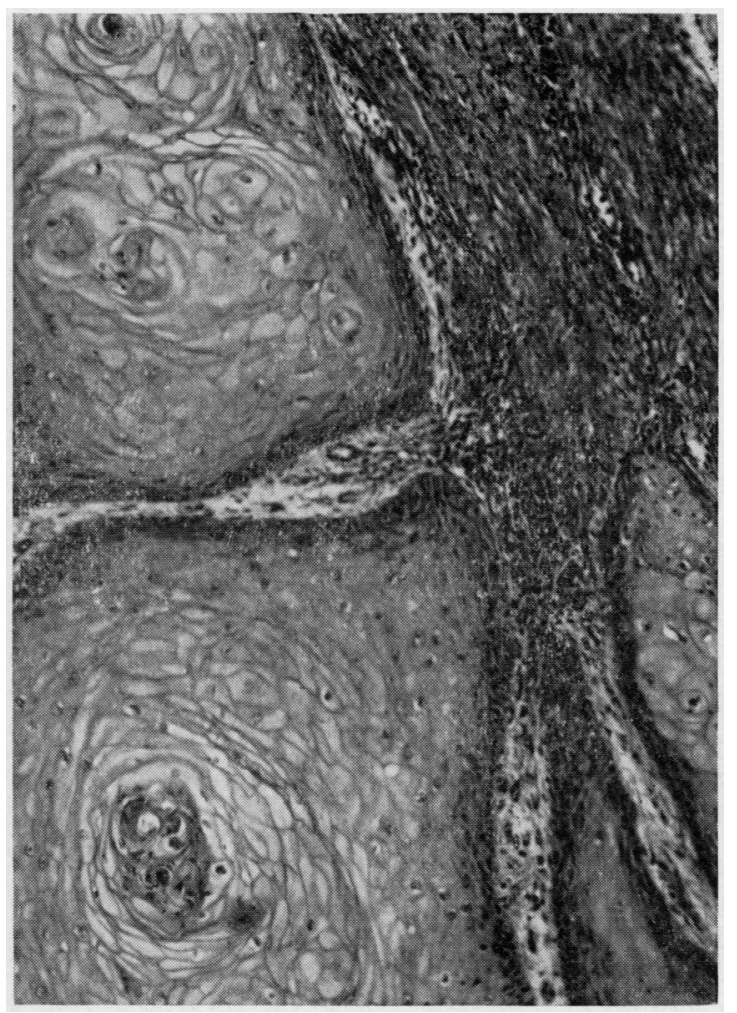

FIG. 9

FIG. 8. Single process showing variation in nuclear size and staining; centre contains keratin $\times 25$.

FIG. 9. Process showing pale, finely outlined cells, few prickle cells $\times 25$.

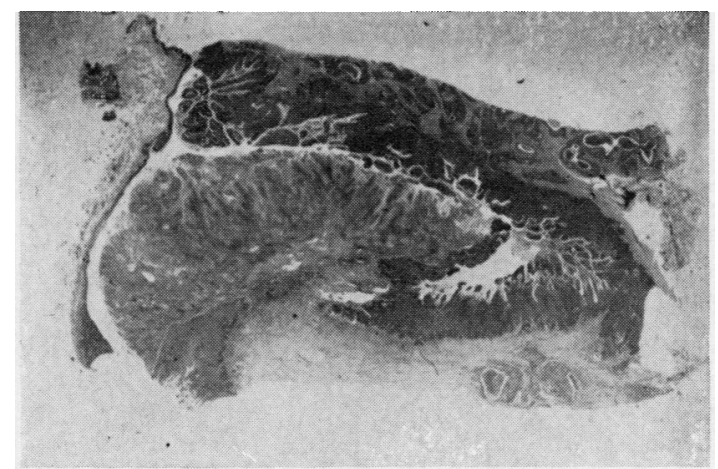

FIG. 10. Malignant condyloma and area of solid papillary epithelioma $\times 4$.

Narrow bands of abnormally dividing cells are found between the processes and extend from the outer margins. Again, in the sections which were examined the particular pattern of tumour was found to be constant, but in two cases areas of solid papillary epithelioma were observed (Fig. 10).

By the absence of prickle cell preponderance, the increased basal cell activity and central keratinization, the malignant condyloma occupies an intermediate position between giant condyloma and squamous cell carcinoma.

GROUP C: SOLID PAPILLARY EPITHELIOMA (FIGS. 11, 12) The overall appearance of this tumour bears a 
superficial resemblance to the giant condyloma. It may form broad rounded processes or wide sheets of cells without, however, any lines of demarcation. The cells are of uniform appearance with dense cytoplasm, large hyperchromic nuclei, and many mitoses; there are no intercellular bridges. Flecks of keratohyaline material are scattered in all areas, and any spaces within the tumour are filled with inflammatory cells. The solid papillary epithelioma shows little resemblance either to malignant condyloma or squamous cell carcinoma.

The histological appearances in groups A, B, and $\mathrm{C}$ are compared in Table III.

GROUP D: SQUAMOUS CELL CARCINOMA (FIGS. 13, 14) There were several grades of squamous cell carcinoma varying from the well-differentiated type with typical epithelial pearls to an anaplastic variety consisting of irregular fine strands of malignant cells which infiltrate widely in a plexiform manner. In contrast to the tumours described in groups, I, II, and III the well-differentiated squamous cell carcinoma forms no true processes. The outlines of the advancing masses of cells are jagged and illdefined and invade the tissues without any lines of limitation. There is no particular preponderance of prickle cells and all types of epithelial cells are represented. The local epithelium frequently shows widening of the rete pegs, marked irregularity in arrangement of the basal cells with hyperchromatic nuclei and, in some examples, early carcinoma in situ.

GROUP E: BASAL CELl CARCINOMA This tumour consists of small rounded clumps of cells with some palisade arrangement at the periphery. It is generally superficial. In comparison with the solid papillary epithelioma the tumour cells have pale cytoplasm and few mitoses. There are no intercellular bridges.

GROUP F: MISCELLANEOUS TUMOURS This group includes three cases of malignant melanoma, one fibrosarcoma, and one adenocarcinoma probably arising from Littre's glands.

\section{CLINICAL DETAILS AND DISCUSSION}

From Table II it may be seen that none of the patients with giant condyloma died from carcinoma of the penis. When lymph nodes could be examined these were free from secondary tumour.

DURATION OF SYMPTOMS In some recorded cases there was extensive involvement of the genitalia over a period of four to six months (Powley, 1964) but, in general, the duration of symptoms is long, as shown by the following case.

Case 1 The patient had warty tumours of the penis since 1937 when he was 53 years of age. In 1957 he received radiotherapy and in 1959 radical amputation of the penis was performed; sections showed the tumour to be a giant condyloma. He died in 1961 due to ascending urinary infection and there was no evidence of residual or secondary tumour at post-mortem examination.

RECURRENCE It is well recognized that the giant condyloma may recur following surgical treatment. This may be due to incomplete removal of deeper portions of the tumour and recurrence is apparent rather than real. The widespread hypertrophy of the prickle cell layers of the squamous epithelium has been mentioned and a multicentric nature of origin may give rise to further condylomata after excision of previous tumour in the area. Except in rare cases (Grisson and Delbanco, 1915; Treite, 1941) when the tumour recurs, the histology remains entirely benign and identical to that of previous sections from the same case as shown by the following report.

Case 2 The patient had penile warts since 1927. In 1957 , at the age of 57, he developed urethral fistula and a partial amputation of the penis was performed. Sections of the tumour showed benign giant condyloma. In January 1964 two small warty tumours were excised from the skin of the penile stump which, on histological examination, were found to be small condyloma acuminata.

TABLE III

COMPARISON OF THE HISTOLOGICAL FEATURES IN GROUPS A, B, AND C

\begin{tabular}{lll} 
Giant Condyloma Acuminata & Malignant Condyloma & Solid Papillary Epithelioma \\
\hline $\begin{array}{l}\text { Wide rounded processes with well- } \\
\text { demarcated lower limits }\end{array}$ & $\begin{array}{l}\text { Processes are narrow, multiple and often } \\
\text { irregular in outline } \\
\text { Inactive basal cell layers }\end{array}$ & Bctive basal cell layers, frequent mitoses and rounded processes \\
$\begin{array}{l}\text { Processes are composed mainly of typical } \\
\text { prickle cells } \\
\text { Little keratinization within the tumour }\end{array}$ & $\begin{array}{l}\text { Decrease of typical prickle cells } \\
\text { Inclated clumps of tumour beyond the } \\
\text { main mass }\end{array}$ & $\begin{array}{l}\text { Uniform cellular appearance, no prickle } \\
\text { cells, many mitoses }\end{array}$ \\
$\begin{array}{l}\text { Centres contain inflammatory cells and } \\
\text { free nucleated epithelial cells }\end{array}$ & $\begin{array}{l}\text { vacuolation of cells and mitoses } \\
\text { Centres contain keratin in addition to } \\
\text { inflammatory and epithelial cells }\end{array}$ &
\end{tabular}




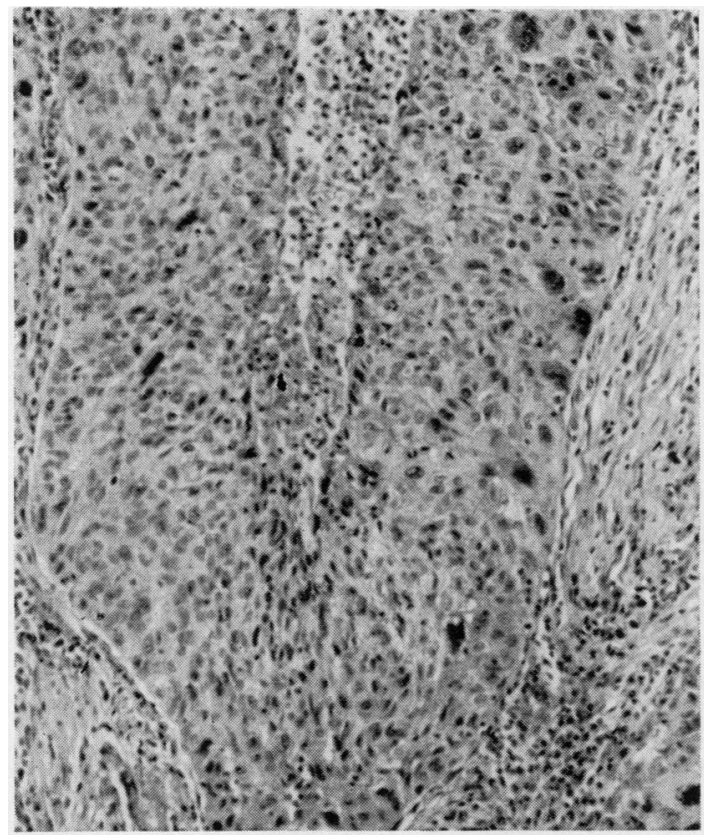

FIG. 11. Process showing superficial resemblance to giant condyloma; many mitoses $\times 25$.

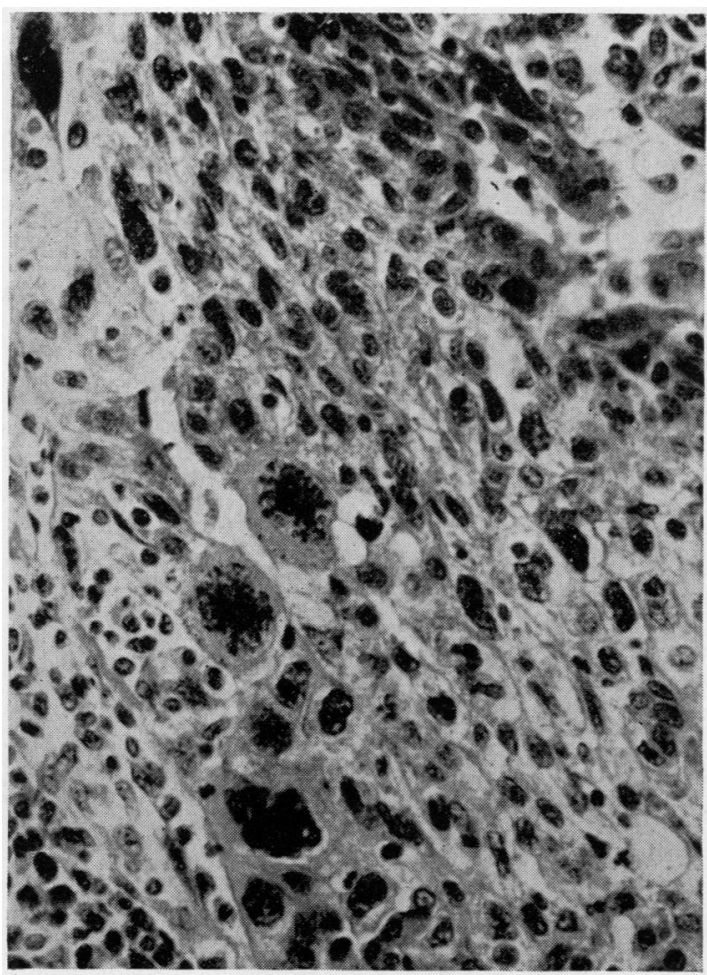

FIG. 12. Solid papillary epithelioma $\times 40$.

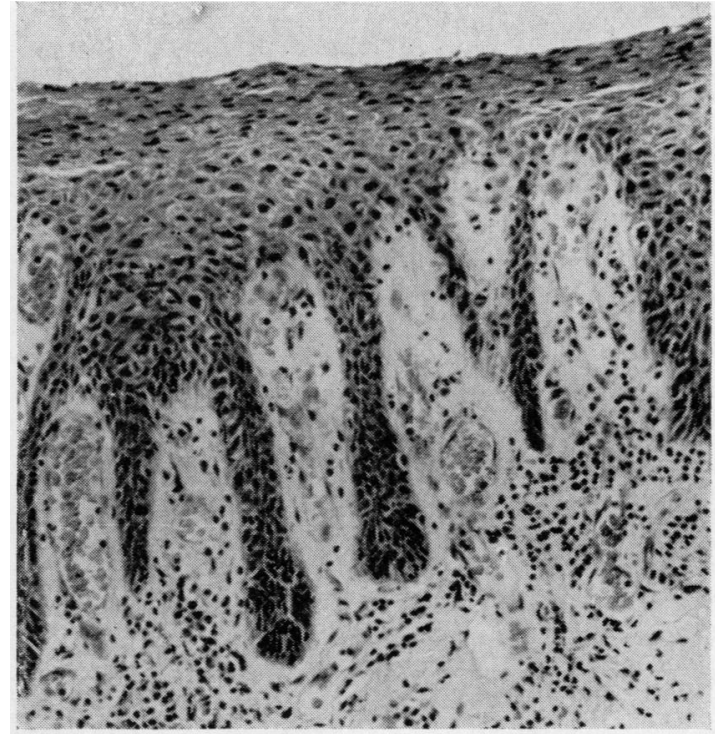

FIG. 13. Local epithelium $\times 10$.

MALIGNANT CHANGE Malignant change is extremely rare and only two cases from the literature can be accepted with any certainty. These are described by Triete (1941) and by Grisson and Delbanco (1915). Both had a long clinical history, 12 and 16 years respectively, and the former occurred in the clitoris. The tumours underwent transition from benign condyloma to malignant condyloma and finally, to solid papillary epithelioma. The following case in this series is described.

Case 3 The patient developed penile warts in 1948 at the age of 30 . He was circumcised shortly after the appearance of the early lesions and was treated from time to time with local applications and systemic antibiotics. In 1960 there were masses of warts covering the glans and the circumcised edge of the prepuce. Biopsy of the tumour showed the histological features of giant condyloma but some large hyperchromatic cells were found, scattered irregularly, in one area. The patient was treated by total amputation of the penis and dissection of the regional lymph nodes. Sections from the operation specimen showed a similar pattern to that of the biopsy and confirmed that malignant change was present (Figs. 15, 16, and 17). The regional lymph nodes showed marked inflammatory hyperplasia but no metastases. The patient was well until 1963, and then two small firm masses were found in the groins. These were excised and on histological examination did not show any evidence of recurrent tumour; one contained lymphoid tissue showing reactive hyperplasia, the other consisted of fibrous tissue and inflammatory cells. The overlying skin showed considerable hypertrophy of the prickle cell layers. 
THE MALIGNANT CONDYLOMA The cases diagnosed as malignant condyloma have a relatively short clinical history (Table II). This may be interpreted to suggest that the malignant tumour represents a rapid generalized transition from the benign tumour; alternatively, it may well be malignant from the beginning. The histological relationship between the benign and malignant tumour is demonstrated by the reports of Treite and Grisson and Delbanco but in both cases there was a long clinical history.

The sections from the patients who died from carcinoma showed, in a florid manner, the characteristic features of malignant condyloma. The remaining cases demonstrated one or more of these features but because of these changes the tumours were not included in group $\mathrm{A}$ and were considered to be essentially malignant. The lymph nodes from cases of malignant condyloma contained metastases.

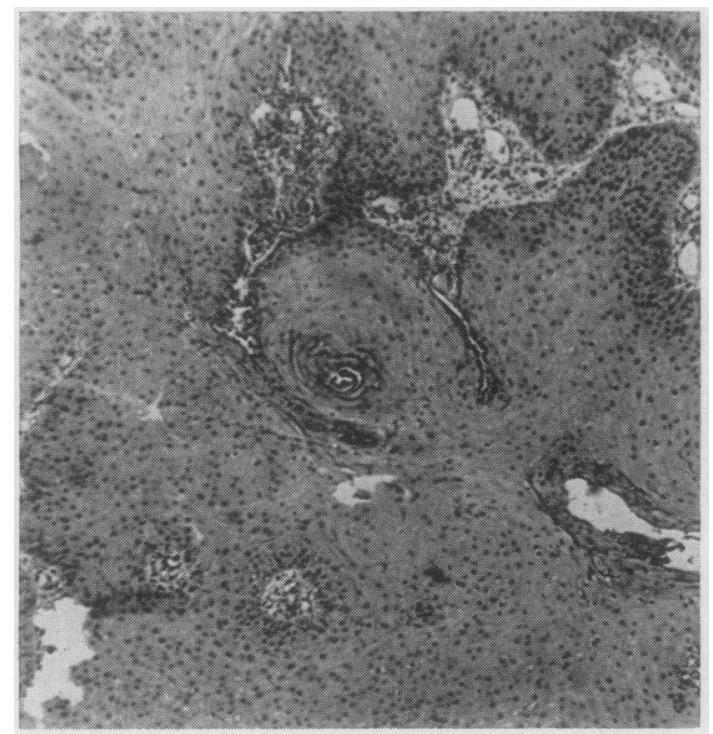

FIG. 14

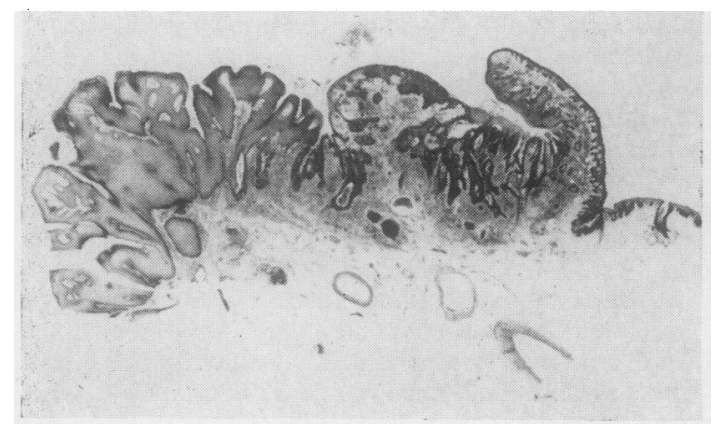

FIG. 15
Some cases of giant condyloma have been reported in which there were metastases in the regional lymph nodes. The histological description of these tumours included hyperkeratosis among other features. From the criteria which have been described these were examples of malignant condyloma and not benign tumour.

SOLID PAPILLARY EPITHELIOMA In this group of cases, again, the duration of symptoms is short. There were deaths from carcinoma and the lymph nodes contained metastases.

SQUAMOUS CELL CARCINOMA It was noted that in this group all the lymph nodes which were examined contained tumour metastases, and many of these occurred in association with well-differentiated

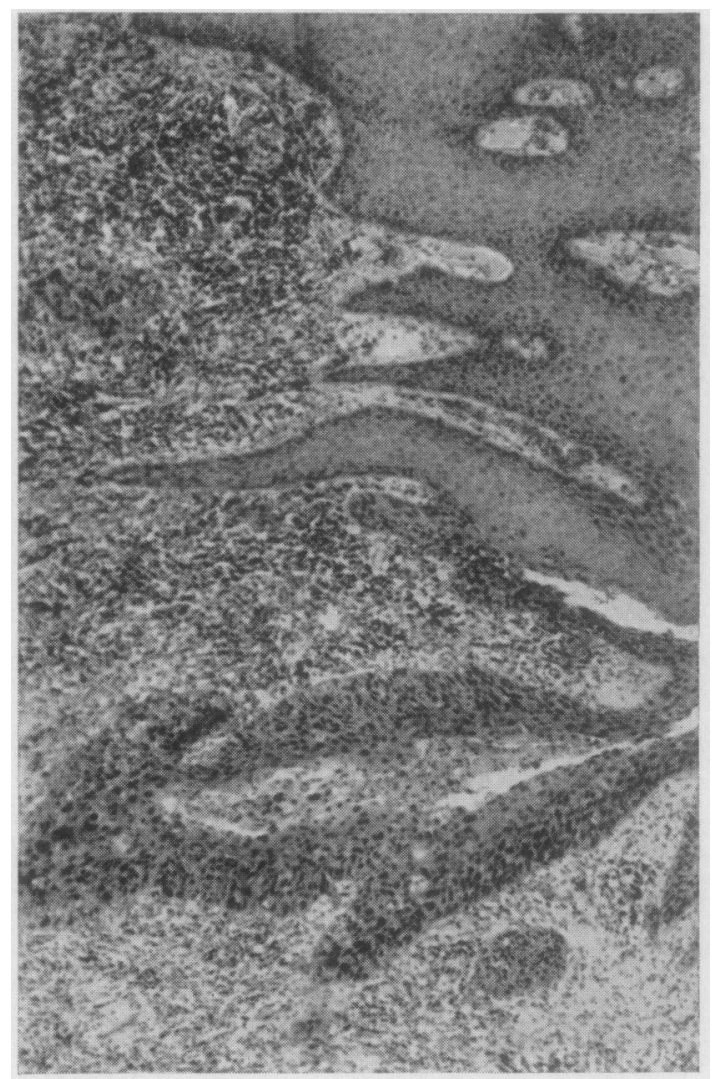

FIG. 16

FIG. 14. Section from operation specimen in case $3 \times 4$. FIc. 15. Area of tumour showing giant condyloma in case $3 \times 10$.

FIG. 16. Area of malignant change in case $3 \times 10$. 
primary tumour and showed a similar histological pattern.

\section{CONCLUSION}

There is undoubtedly a particular warty tumour of the penis which is associated often, but not invariably with a long clinical history. Although the benign tumour may recur the clinical prognosis is excellent. Malignant change is rare.

The malignant condyloma and solid papillary epithelioma require careful differentiation from the benign condyloma and the clinical prognosis for these tumours is similar to that for squamous cell carcinoma.

I wish to thank Dr. Mavis McConnell and her staff of the Liverpool Cancer Control Organization for their help in making available case reports and sections, and Professor H. L. Sheehan for his interest both in the histological interpretation of the sections and the presentation of the paper.

Mr. I. W. MacPhee, consultant surgeon to the
Liverpool Royal Infirmary, kindly gave his permission for the report on case 3.

\section{REFERENCES}

Buschke, A. (1896). In Stereoscopischer medicinischer Atlas, edited by A. Neisser. Fischer, Cassel.

and Loewenstein, L. (1932). Dsch. med. Wschr., 58, 809.

Davies, S. Walker (1964). Brit. J. Surg., 51, 338.

Delbanco, E. (1925). Derm. Z., 45, 134.

Dreyfuss, W., and Neville, W. E. (1955). Amer. J. Surg., 90, 146.

Fisher, I., and Haas, C. F. (1955). Minn. Med., 38, 423.

Freudenthal, W., and Spitzer, R. (1933). In Handbuch der Haut- und Geschlechtskrankheiten, edited by J. Jadassohn, vol. 12, pt. 3 , pp. 33-207. Springer, Berlin.

Frei, W. (1930). Arch. Dermat. Syph. (Berl.), 160, 109.

Gersh, I. (1953). J. Urol. (Baltimore), 69, 164.

Grisson, and Delbanco, E. (1915). Derm. Wschr., 60, 89.

Israel, W. (1928a). Z. Urol., 221, 395.

- (1928b). Derm. Wschr., 87, 1217.

Lepow, H., and Leffler, N. (1960). J. Urol. (Baltimore), 83, 853.

Loewenstein, L. W. (1939). Med. Clin. N. Amer., 23, 789.

Montagnani, A. (1957). Rif. med., 71, 869.

Mühlpfordt, H. (1928). Derm. Wschr., 87, 1403.

- (1931). Ibid., 93, 1145.

Powley, J. M. (1964). Brit. J. Surg., 51, 76.

Treite, P. (1941). Zbl. Gynäk., 65, 1096.

Unna, P. G. (1894). Die Histopathologie der Hautkrankheiten. Hirschwald, Berlin. 